\title{
Evaluation of the use of different prophylactic antibiotic protocols in surgically assisted rapid maxillary expansion: A controlled, double-blind, randomized clinical study
}

Avaliação do emprego de diferentes protocolos de antiboticoterapia profillática na expansão rápida de maxila assistida cirurgicamente: Um estudo clínico controlado, duplo cego, randomizado Evaluación del uso de diferentes protocolos antibióticos profilácticos en la expansión maxilar rápida asistida por cirugía: Un estudio clínico controlado, doble ciego, aleatorizado

Maykel Sullyvan Marinho de Souza ORCID: https://orcid.org/0000-0002-0625-1738 Federal University of Ceará, Brazil

E-mail: maykelmarinho@ hotmail.com

Marcelo Leite Machado da Silveira ORCID: https://orcid.org/0000-0002-8628-0570 Federal University of Ceará, Brazil E-mail: marceints@hotmail.com Soraia Rodrigues de Gois ORCID: https://orcid.org/0000-0002-5291-3739 Federal University of Ceará, Brazil

E-mail: soraia_rodriguess@icloud.com

Fabrício De Lamare Ramos ORCID: https://orcid.org/0000-0003-2234-9388 Federal University of Ceará, Brazil E-mail: flamareramos@gmail.com

Francisco Samuel Rodrigues Carvalho ORCID: https://orcid.org/0000-0002-3142-1268 Federal University of Ceará, Brazil

E-mail: samuel.rcarvalho@gmail.com

Tácio Pinheiro Bezerra ORCID: https://orcid.org/0000-0002-1058-4172 Federal University of Ceará, Brazil

E-mail: drtpb@hotmail.com

Fábio Wildson Gurgel Costa ORCID: https://orcid.org/0000-0002-3262-3347 Federal University of Ceará, Brazil E-mail: fwildson@yahoo.com.br

Rafael Linard Avelar

ORCID: https://orcid.org/0000-0003-2984-3063 Federal University of Ceará, Brazil E-mail: rafael.linard@hotmail.com

João Octavio Pompeu Hyppolito ORCID: https://orcid.org/0000-0002-6278-4387 Universidade de Fortaleza, Brazil

E-mail: joao_hyppolito@hotmail.com

Eduardo Costa Studart Soares ORCID: https://orcid.org/0000-0002-4880-1240 Federal University of Ceará, Brazil E-mail: estudart@yahoo.com.br

\begin{abstract}
Data related to postoperative infection in surgically-assisted rapid maxillary expansion (SARME) are scarce. Our goal was to compare the effects of two different prophylactic antibiotic regimens on infection rates in patients undergoing SARME. A randomized, double-blind clinical trial was carried out with 23 patients (06 men and 17 women) who received $1 \mathrm{~g}$ cefazolin one hour before the procedure (Group $1-\mathrm{G} 1$ ) or $1 \mathrm{~g}$ cefazolin one hour before the procedure and again in the first 24 postoperative hours (Group $2-$ G2). Patients were followed up for one month after surgery. Pain was greater in G1 with a statistically significant difference in the follow-ups of 1, 2, 7 and 21 postoperative days $(\mathrm{p}<0.05)$. Variable such as edema, erythema, fever, abscess and drainage did not differ between groups. Despite the
\end{abstract}


similarities between the groups, the total sum of inflammatory events was 17 times higher in G1 ( $p<0,001)$. A single dose of cefazolin $1 \mathrm{~g}$ one hour before the procedure is sufficient to prevent infection in patients undergoing SARME. These findings may help to decrease the indiscriminate use of antibiotics in in these situations, thus preventing the emergence of bacterial resistance and complications associated with the use of antibiotics.

Keywords: Palatal expansion technique; Surgical wound infection; Antibiotic prophylaxis.

\section{Resumo}

Dados relacionados à infecção pós-operatória em expansão rápida de maxila assistida cirurgicamente (ERMAC) são escassos. Nosso objetivo foi comparar os efeitos de dois esquemas de antibioticoterapia profilática sobre os índices de infecção nos pacientes submetidos a ERMAC. Foi realizado um ensaio clínico, randomizado, duplo cego, com 23 pacientes (06 homens e 17 mulheres) que receberam cefazolina $1 \mathrm{~g}$ uma hora antes do procedimento (Grupo 1 - G1) ou cefazolina $1 \mathrm{~g}$ uma hora antes do procedimento e nas primeiras 24 h pós-operatórias (Grupo 2 - G2). Os pacientes foram acompanhados por um mês pós-operatório. O sintoma dor foi maior no G1 com uma diferença estatisticamente significativa nos acompanhamentos de 1, 2, 7 e 21 dias de pós-operatório ( $<<0,05)$. As variáveis edema, eritema, febre, abscesso e drenagem não diferiram entre os dois grupos. Apesar da similaridade entre os grupos, a soma total de eventos inflamatórios foi 17 vezes maior no $\mathrm{G} 1(\mathrm{p}<0,001)$. Uma dose única de cefazolina $1 \mathrm{~g}$ uma hora antes do procedimento é suficiente para prevenir infecção em pacientes submetidos a ERMAC. Esses achados podem auxiliar a diminuir o uso indiscriminado de antibióticos nessas situações, assim prevenindo o surgimento de resistência bacteriana e complicações associadas ao uso de antibióticos.

Palavras-chave: Técnica de expansão palatina; Infecção da ferida cirúrgica; Antibioticoprofilaxia.

\section{Resumen}

Los datos relacionados con la infección postoperatoria en la expansión maxilar rápida asistida quirúrgicamente (EMRAC) son escasos. Nuestro objetivo fue comparar los efectos de dos regímenes de antibióticos profilácticos sobre las tasas de infección en pacientes sometidos a EMRAC. Se realizó un ensayo clínico aleatorizado, doble ciego con 23 pacientes (06 hombres y 17 mujeres) que recibieron cefazolina $1 \mathrm{~g}$ una hora antes del procedimiento (Grupo 1 - G1) o cefazolina $1 \mathrm{~g}$ una hora antes del procedimiento y en las primeras $24 \mathrm{~h}$ postoperatorias (Grupo 2 - G2). Los pacientes fueron seguidos durante un mes después de la operación. El síntoma de dolor fue mayor en G1 con diferencia estadísticamente significativa en los seguimientos de 1, 2, 7 y 21 días postoperatorios ( $\mathrm{p}<0,05)$. Las variables edema, eritema, fiebre, absceso y drenaje no difirieron entre los dos grupos. A pesar de la similitud entre los grupos, la suma total de eventos inflamatorios fue 17 veces mayor en G1 ( $p<0,001)$. Una sola dosis de $1 \mathrm{~g}$ de cefazolina una hora antes del procedimiento es suficiente para prevenir infecciones en pacientes sometidos a EMRAC. Estos hallazgos pueden ayudar a disminuir el uso indiscriminado de antibióticos en estas situaciones, evitando así la aparición de resistencias bacterianas y las complicaciones asociadas con el uso de antibióticos.

Palabras clave: Técnica de expansión palatina; Infección de la herida Quirúrgica; Profilaxis antibiótica.

\section{Introduction}

Maxillary transverse deficiency (MTD) is a deformity characterized by unilateral or bilateral posterior crossbite. Patients may have an ogival palate, crowding and nasal breathing difficulties. (Barbosa et al., 2020; de Gijt et al., 2017; Iodice et al., 2013; Koudstaal et al., 2005) Although there is little data in the literature regarding the incidence of MTD in adults, (Suri \& Taneja, 2008) between 8 to $18 \%$ of patients seeking orthodontic treatment have this deformity, which may reach $24 \%$. (Filho et al., 1991; Sato et al., 2014) The most common treatment modalities for MTD include orthopedic maxillary expansion (OME), compensatory orthodontics, surgically-assisted rapid maxillary expansion (SARME) and segmental maxillary osteotomy during orthognathic surgery. (Suri \& Taneja, 2008; Bays \& Greco, 1992; Betts, 2016; Northway \& Meade, 1997)

Although considered a surgical modality inserted in the orthognathic surgery universe, the incisions and osteotomies used in SARME are more conservative. SARME is a technique which is indicated in cases of patients with MTD and who have skeletal maturation due to ossification of the sutures. (Suri \& Taneja, 2008; Betts, 2016) Although it is possible to perform maxillary expansion with segmentation concomitant with Le Fort I osteotomy, there are advantages to performing SARME as a previous procedure. The performance of multiple osteotomies, especially on patients with major deformities, can result in greater instability and relapse after removing orthodontic devices. In addition, there is a higher risk of aseptic maxillary necrosis when this procedure is performed in conjunction with Le Fort I osteotomy. (Iodice et al., 2013; Betts, 2016; Laningan \& Mintz, 2002) 
Any invasive surgical procedure results in the production of a surgical wound and it is important to know its contamination degree to institute antibiotic therapy when necessary. Surgical wounds can be divided into classes I, II, III or IV, according to the contamination degree which is expected. The surgeries in which there is no rupture of the respiratory, urinary or gastrointestinal (GI) tracts and without breaking the aseptic chain are classified as class I, or clean surgeries. Class II surgeries, or clean-contaminated surgeries, are those with the rupture of one of the three respiratory, urinary or GI tracts, without significant bacterial contamination. Class III surgery, also called contaminated surgery, occurs when there is a release of secretions from the GI tract or entry into the infected urinary or biliary tract. Fresh traumatic wounds (less than eight hours) are also classified as class III. Finally, Class IV surgeries, or dirty-contaminated surgeries, occur when there is an established clinical infection or a traumatic wound which occurred more than eight hours ago. (Peterson, 1990)

Based on this classification proposed by Peterson, SARME is a class II surgery and requires prophylactic antibiotic therapy to reduce the risks of postoperative infection. (Peterson, 1990) The goal of prophylactic antibiotic therapy is to prevent a possible infection of the surgical wound through serum concentrations of antibiotics capable of preventing bacteria from multiplying. (Danda \& Ravi, 2011) However, this pharmacological approach remains controversial in orthognathic surgery. To date, there is no consensus on the type and duration of the prophylactic antibiotic therapy regimen, and this is probably due to the lack of properly developed randomized clinical trials. (Danda \& Ravi, 2011; Bentley et 1., 199; Tan \& Zwahlen, 2011)

Another issue discussed in the literature is the emergence of bacterial resistance. (Danda \& Ravi, 2011; Ruggles \& Hann, 1984) In a systematic review published in 2010, it was observed that both long-term and recurrent use of antibiotics were associated with the development of bacterial resistance and that, as far as the greater the number of antibiotics prescribed, the greater the chance of the emergence of resistant bacteria. (Costelloe et al., 2010)

Most published studies on SARME focus on surgical technique and postoperative stability with little emphasis on its complications. (Koudstaal et al.; 2005; Suri \& Taneja, 2008; Koudstaal et al. 2009; Kraut, 1984) Despite this, this surgery is not risk-free, and the surgeon should keep an eye out for potential complications. (Bays \& Greco, 1992; Laningan \& Mintz, 2002)

Considering the scarcity of studies in the literature which have evaluated the use of prophylactic antibiotic therapy in patients undergoing SARME and the scarcity of guidelines regarding prophylactic regimens to be instituted, the objective of the present study is to evaluate two prophylactic antibiotic therapy protocols and their effects on the infection rates in patients undergoing SARME.

\section{Methodology}

\section{Study design and sample}

This is a randomized, double-blind clinical trial composed of patients who seeked treatment in the Oral-Maxillofacial Surgery and Traumatology Service of the Walter Cantídio University Hospital of the Federal University of Ceará. The study was approved by the institution's human research ethics committee under the registration number CAAE30398113.0.0000.5045 and followed CONSORT 2010 guidelines. (Schulz et al., 2011) Healthy individuals (ASA I classification from the American Society of Anesthesiology) of both genders aged between 18 and 45 years and who agreed to participate in the study after reading and signing the informed consent form were included, along with indication for SARME after the diagnosis based on the criteria of Koudstaal-2009 (Koudstaal et al., 2009) which include: unilateral or bilateral transverse jaw atresia, posterior crossbite, anterior or posterior dental crowding, clinically visible buccal corridor and patients with skeletal maturation. Patients who met at least one of the following criteria were excluded from the study: smokers, alcohol drinkers and users of illicit drugs; pregnant or lactating patients; users of any medications which interact with the drugs used in this study; patients with chronic systemic changes or who use immunosuppressive medications; patients allergic to the drugs 
used in the study; patients who underwent head or neck radiation therapy; patients who underwent previous surgical procedure on the maxilla; and patients who used antibiotic medication up to two weeks before the surgical procedure. Patients who did not follow the postoperative recommendations or who did not return for reevaluation appointments were removed from the study. Figure 1 shows the patient flow diagram.

Figure 1: Flow diagram according to the CONSORT statement.

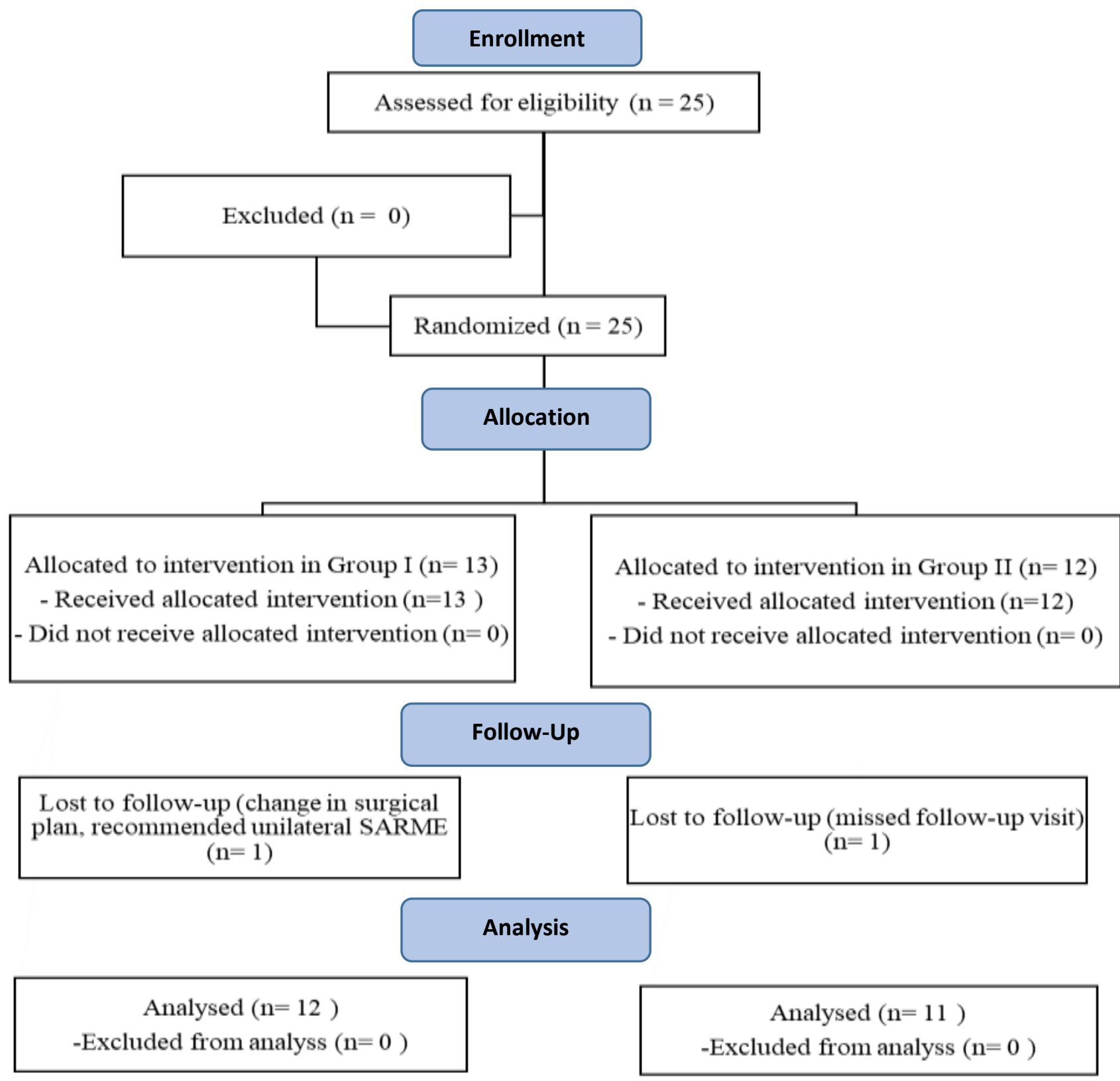

Source: Authors.

Patients who met the inclusion criteria were randomly allocated into two groups:

- $\quad$ Group I: administration of $1 \mathrm{~g}$ cefazolin intravenously in a single dose in the immediate preoperative period (one hour before the procedure) and intravenous administration of $0.9 \%$ saline without antibiotics every six hours in the first 24 hours after surgery; 
- $\quad$ Group II: administration of $1 \mathrm{~g}$ cefazolin intravenously in a single dose in the immediate preoperative period (one hour before the procedure) and intravenous administration of $0.9 \%$ saline with the antibiotic cefazolin every six hours in the first 24 hours after surgery.

The antibiotic used in both groups was sodium Cefazolin powder for solution for injection (Cefazolin, Pharmacist in charge: Paulo Fernando Bertachini, Aurobindo Pharma Indústria Farmacêutica Limitada, Anápolis/GO).

\section{Blinding}

The patient, the researcher and the statistician did not know which group each patient belonged to. An envelope containing the drug protocol assigned to each patient was kept sealed by an external collaborator prior to the surgical procedure. The evaluator and the patient remained unaware of this information until the final data analysis. The researcher did not have access to the patient's daily prescription in the postoperative evaluation, which was performed by a resident who was not part of the research.

\section{Randomization}

The method used to generate the random sequence was the 'randbetween' function in Microsoft Excel, version 2010. Randomization was based on the simple type, without any restrictions. Numbered envelopes were used to implement the random allocation sequence. Each envelope contained information specifying the group to which the patient belonged. A collaborating researcher who did not participate in the surgical procedures was responsible for generating the random allocation sequence, as well as for organizing and distributing the participants into each group.

\section{Sample size calculation}

Based on the work of Bentley et al., 1999, who evaluated patients undergoing orthognathic surgery and observed a $6.7 \%$ infection rate in the group treated with penicillin $\mathrm{G}$ and $60.0 \%$ in the group treated with placebo, it is estimated that it is necessary to evaluate 19 patients (Fleiss method with correction continuity) in order to obtain a sample that represents with 90\% power and 95\% confidence groups of patients undergoing surgically-assisted rapid maxillary expansion (SARME) and different antibiotic regimens. However, $20 \%$ was added in view of the possibility of sample loss, thus totaling 23 patients.

\section{Surgical technique}

All patients underwent a standardized surgical technique performed in a hospital environment and under general anesthesia using nasotracheal intubation. The procedures were performed by residents of the third year of Oral and Maxillofacial Surgery and Traumatology of the Oral and Maxillofacial Surgery and Traumatology Residency Program at the Walter Cantídio University Hospital of the Federal University of Ceará.

After submucosal infiltration of a local anesthetic associated with a vasoconstrictor (2\% lidocaine hydrochloride, Hipobalor ${ }^{\circledR}$ and Hydren ${ }^{\circledR}$, epinephrine $1 \mathrm{mg} / \mathrm{mL}$ ) bilaterally in the buccal groove, a bilateral mucoperiosteal incision of 3 to 5 $\mathrm{mm}$ above the mucogingival junction was bilaterally performed from the mesial of the canine to the mesial of the first molar. In addition, an incision was made in the midline in a "V" shape above the upper central incisors. Then, periosteal dissection was performed to expose the lateral maxilla wall and the outline of the piriform opening, in addition to the anterior midline of the maxilla and anterior nasal spine. Markings were made $5 \mathrm{~mm}$ above the apexes of the canines and 1 st molars to guide the osteotomies which were planned on the lateral maxilla wall, which extended from the piriform opening to the pterygomaxillary junction, with the latter being separated using a chisel and hammer. Then, the Hyrax appliance was activated and a chisel and hammer was used in the anterior region between the central incisors to promote palatal disjunction. Once the separation was 
confirmed, the device was kept open at $1 \mathrm{~mm}$. The suture was performed with resorbable threads (Polyglactin 910, thickness 4.0, needle 2.2, polysuture $\square$ ).

After surgery, analgesic (500 mg dipyrone sodium, Teuto®) and anti-inflammatory (100 mg/2 mL Profenid® ketoprofen, Sanofi Aventis $\left.{ }^{\circledR}\right)$ medications were prescribed. Antiemetic medication $\left(8 \mathrm{mg} / \mathrm{mL}\right.$ Ontrax ${ }^{\circledR}$ Ondasentrone, Blau $\left.{ }^{\circledR}\right)$ was prescribed if necessary. Subsequent activation of the device started five days after the surgical procedure at an intensity/frequency of $1 \mathrm{~mm} /$ day until the crossbite was corrected.

\section{Data acquisition}

All follow-up and postoperative evaluation stages were performed by a single evaluator who was trained to detect clinical signs of infection. Calibration occurred through postoperative evaluation of patients undergoing SARME who would not be part of the study. Thus, the evaluator was able to monitor the postoperative evolution and detect any change patterns which occurred naturally during this period.

The patients were clinically evaluated by the main researcher prior to the surgical procedure and a standardized form was filled out, which included data regarding patient identification, socioeconomic status, main complaint, history of the main complaint, current and past medical history, deleterious habits, and current and past dental history. The primary outcome of the study was the occurrence of postoperative infection. Local infection investigation followed the criteria from the Centers for Disease Control and Prevention (CDC) of 1999 (Mangram et al., 1999) and was performed in each evaluation period.

Data regarding the presence of purulent drainage, localized edema, erythema, suture dehiscence and presence of abscesses or infection of deep spaces (1999 CDC criteria) (Mangram et al., 1999) were recorded individually as present or absent, and collected during the pre-operative period, each day the patient remained hospitalized (two days) and on each postoperative return at 7, 14, 21 and 28 days after hospital discharge, completing 30 postoperative days. Body temperature was measured by the axillary temperature in degrees Celsius by means of a thermometer (Accumed) at each evaluation moment. The presence of fever was confirmed if the body temperature was above $38^{\circ} \mathrm{C}$.

The secondary outcome was postoperative pain, with pain intensity being measured using a visual analog scale (VAS) with scores between 0 (no pain or discomfort) and 10 (maximum pain). The patients completed the VAS at all evaluation moments.

\section{Statistical analysis}

The data were tabulated in Microsoft Excel and then exported for analysis into the Statistical Package for the Social Sciences (SPSS) software version 20.0 for Windows, adopting a 95\% confidence interval.

The absolute frequencies and percentages of each inflammatory event were expressed and compared using the Fisher's exact test (analysis between groups) or Pearson's chi-squared test (intra-group analysis). Additionally, the mean \pm standard error was calculated for the sum of inflammatory events per patient, which were compared along with age using the Student's t-test.

\section{Results}

A total of 25 patients were initially included in the study. However, two were excluded: one for having to do unilateral expansion; and another for not returning to the postoperative consultation. (Figure1) The final sample consisted of 23 patients of both genders ( 6 men and 17 women), representing $26 \%$ and $74 \%$ of the sample, respectively. Thus, there was a predominance of female patients in both groups, but without statistical difference between them $(p=0.640)$. (Table 1$)$ 
Table 1: Variables analyzed for the comparison between groups submitted to SARME using two different antibiotic prophylaxis protocol.

\begin{tabular}{|c|c|c|c|c|c|c|c|}
\hline & \multicolumn{6}{|c|}{ Group } & \multirow[b]{2}{*}{ p-Value ${ }^{a}$} \\
\hline & \multicolumn{2}{|c|}{ Total } & \multicolumn{2}{|c|}{ G1 } & \multicolumn{2}{|c|}{ G2 } & \\
\hline Sex & & & & & & & \\
\hline Female & 17 & $74 \%$ & 8 & $67 \%$ & 9 & $82 \%$ & 0,640 \\
\hline Male & 6 & $26 \%$ & 4 & $33 \%$ & 2 & $18 \%$ & \\
\hline Purulent drainage & & & & & & & \\
\hline Preoperative & 0 & $0 \%$ & 0 & $0 \%$ & 0 & $0 \%$ & 1,000 \\
\hline 1 day postoperative & 1 & $4 \%$ & 0 & $0 \%$ & 1 & $9 \%$ & 0,478 \\
\hline 2 days postoperative & 0 & $0 \%$ & 0 & $0 \%$ & 0 & $0 \%$ & 1,000 \\
\hline 1 week postoperative & 0 & $0 \%$ & 0 & $0 \%$ & 0 & $0 \%$ & 1,000 \\
\hline 2 weeks postoperative & 0 & $0 \%$ & 0 & $0 \%$ & 0 & $0 \%$ & 1,000 \\
\hline 3 weeks postoperative & 0 & $0 \%$ & 0 & $0 \%$ & 0 & $0 \%$ & 1,000 \\
\hline 4 weeks postoperative & 0 & $0 \%$ & 0 & $0 \%$ & 0 & $0 \%$ & 1,000 \\
\hline p-Value ${ }^{b}$ & \multicolumn{2}{|c|}{0,419} & \multicolumn{2}{|c|}{1,000} & \multicolumn{2}{|c|}{0,414} & \\
\hline \multicolumn{8}{|l|}{ Pain (>5 in VAS) } \\
\hline Preoperative & 1 & $4 \%$ & 1 & $8 \%$ & 0 & $0 \%$ & 1,000 \\
\hline 1 day postoperative & 5 & $22 \%$ & 5 & $42 \%$ & 0 & $0 \%$ & $* 0,037$ \\
\hline 2 days postoperative & 5 & $22 \%$ & 5 & $42 \%$ & 0 & $0 \%$ & $* 0,037$ \\
\hline 1 week postoperative & 5 & $22 \%$ & 5 & $42 \%$ & 0 & $0 \%$ & $* 0,037$ \\
\hline 2 weeks postoperative & 4 & $17 \%$ & 4 & $33 \%$ & 0 & $0 \%$ & 0,093 \\
\hline 3 weeks postoperative & 5 & $22 \%$ & 5 & $42 \%$ & 0 & $0 \%$ & $* 0,037$ \\
\hline 4 weeks postoperative & 3 & $13 \%$ & 3 & $25 \%$ & 0 & $0 \%$ & 0,217 \\
\hline p-Value ${ }^{b}$ & \multicolumn{2}{|c|}{0,644} & \multicolumn{2}{|c|}{0,512} & \multicolumn{2}{|c|}{1,000} & \\
\hline \multicolumn{8}{|l|}{ Erythema } \\
\hline Preoperative & 0 & $0 \%$ & 0 & $0 \%$ & 0 & $0 \%$ & 1,000 \\
\hline 1 day postoperative & 0 & $0 \%$ & 0 & $0 \%$ & 0 & $0 \%$ & 1,000 \\
\hline 2 days postoperative & 0 & $0 \%$ & 0 & $0 \%$ & 0 & $0 \%$ & 1,000 \\
\hline 1 week postoperative & 0 & $0 \%$ & 0 & $0 \%$ & 0 & $0 \%$ & 1,000 \\
\hline 2 weeks postoperative & 0 & $0 \%$ & 0 & $0 \%$ & 0 & $0 \%$ & 1,000 \\
\hline 3 weeks postoperative & 0 & $0 \%$ & 0 & $0 \%$ & 0 & $0 \%$ & 1,000 \\
\hline 4 weeks postoperative & 0 & $0 \%$ & 0 & $0 \%$ & 0 & $0 \%$ & 1,000 \\
\hline p-Value ${ }^{b}$ & \multicolumn{2}{|c|}{1,000} & \multicolumn{2}{|c|}{1,000} & \multicolumn{2}{|c|}{1,000} & \\
\hline
\end{tabular}




\section{Fever}

\begin{tabular}{|c|c|c|c|c|c|c|c|}
\hline Preoperative & 0 & $0 \%$ & 0 & $0 \%$ & 0 & $0 \%$ & 1,000 \\
\hline 1 day postoperative & 0 & $0 \%$ & 0 & $0 \%$ & 0 & $0 \%$ & 1,000 \\
\hline 2 days postoperative & 0 & $0 \%$ & 0 & $0 \%$ & 0 & $0 \%$ & 1,000 \\
\hline 1 week postoperative & 0 & $0 \%$ & 0 & $0 \%$ & 0 & $0 \%$ & 1,000 \\
\hline 2 weeks postoperative & 0 & $0 \%$ & 0 & $0 \%$ & 0 & $0 \%$ & 1,000 \\
\hline 3 weeks postoperative & 0 & $0 \%$ & 0 & $0 \%$ & 0 & $0 \%$ & 1,000 \\
\hline 4 weeks postoperative & 0 & $0 \%$ & 0 & $0 \%$ & 0 & $0 \%$ & 1,000 \\
\hline p-Value ${ }^{b}$ & & & & & & & \\
\hline
\end{tabular}

\section{Abscess}

Preoperative
1 day postoperative
2 days postoperative
1 week postoperative
2 weeks postoperative
3 weeks postoperative
4 weeks postoperative

$\begin{array}{lllllll}0 & 0 \% & 0 & 0 \% & 0 & 0 \% & 1,000 \\ 0 & 0 \% & 0 & 0 \% & 0 & 0 \% & 1,000 \\ 0 & 0 \% & 0 & 0 \% & 0 & 0 \% & 1,000 \\ 0 & 0 \% & 0 & 0 \% & 0 & 0 \% & 1,000 \\ 0 & 0 \% & 0 & 0 \% & 0 & 0 \% & 1,000 \\ 0 & 0 \% & 0 & 0 \% & 0 & 0 \% & 1,000 \\ 0 & 0 \% & 0 & 0 \% & 0 & 0 \% & 1,000\end{array}$

p-Value ${ }^{b}$

1,000

1,000

1,000

\section{Edema}

$\begin{array}{lccccccc}\text { Preoperative } & 0 & 0 \% & 0 & 0 \% & 0 & 0 \% & 1,000 \\ \begin{array}{l}1 \text { day postoperative } \\ \text { 2 days postoperative }\end{array} & 2 & 9 \% & 1 & 8 \% & 1 & 9 \% & 1,000 \\ \begin{array}{l}\text { 1 week postoperative } \\ \text { 2 weeks postoperative }\end{array} & 0 & 0 \% & 0 & 0 \% & 0 & 0 \% & 1,000 \\ 3 \text { weeks postoperative } & 0 & 0 \% & 0 & 0 \% & 0 & 0 \% & 1,000 \\ 4 \text { weeks postoperative } & 0 & 0 \% & 0 & 0 \% & 0 & 0 \% & 1,000 \\ \text { p-Value } & & 0,216 & 0,657 & 0,655 & \end{array}$

${ }^{*} \mathrm{p}<0,05$, Fisher's exact test or Pearson's qui-square test (n, \%).

${ }^{\mathrm{a} A n a l y s i s ~ b e t w e e n ~ g r o u p s ; ~}{ }^{\mathrm{b}}$ Analysis inside groups.

Source: Authors.

Only one patient in G2 had purulent drainage on the first postoperative day. The prevalence of this symptom decreased to $0 \%$ from the first postoperative week and no significant variation over the evaluation period was seen in $\mathrm{G} 2(\mathrm{p}=$ 0.420). The two groups did not differ at any time during the evaluation $(\mathrm{p}=0,425)$. (Table 1$)$.

The prevalence of patients with pain scores greater than five measured by the VAS was significantly higher in G1 on the first $(\mathrm{p}=0.037)$ and on the second $(\mathrm{p}=0.037)$ postoperative day, as well as on the first $(\mathrm{p}=0.037)$ and third $(\mathrm{p}=0.037)$ postoperative weeks when compared to $\mathrm{G} 2$ patients. There were $42 \%$ of $\mathrm{G} 1$ patients who reported pain equal to or greater than 
5 on the first postoperative day, and this rate decreased to $25 \%$ in the fourth week of follow-up. No patient in G2 had a pain score greater than five points on the VAS $(0 \%)$ (Table 1).

No patient had erythema, fever or abscess, and one patient in each group had edema in the first two postoperative days, with no significant difference between groups $(\mathrm{p}=1.000)$ (Table 1).

The mean sum of inflammatory event scores in G1 patients $(2,58 \pm 0,91)$ was significantly higher than in G2 patients $(0.36 \pm 0.28)(p=0.037)$. (Figure 2$)$ When considering the total number of events suggestive of an inflammatory process, it was observed that the prevalence of G1 events $(\mathrm{n}=31,5,3 \%)$ was $7,1(95 \% \mathrm{CI}=2,49-20,26)$ times higher than $\mathrm{G} 2(\mathrm{n}=4$, $0.7 \%)(\mathrm{p}<0.001)$.

Figure 2: Mean sum of inflammatory event scores in G1 $(2,58 \pm 0,91)$ and $\mathrm{G} 2(0.36 \pm 0.28)$ patients. $(\mathrm{p}=0.037)$.

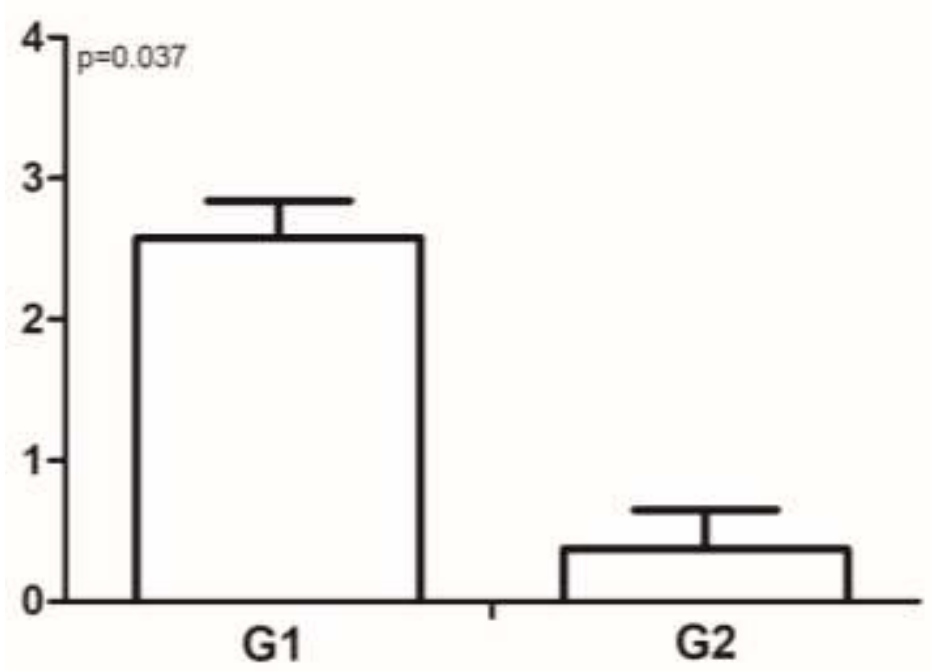

Source: Authors.

\section{Discussion}

The present study evaluated two different protocols of prophylactic antibiotic therapy in SARME and was motivated due to the lack of data about antibiotic protocols in this type of surgery. The fact that SARME is considered a low-risk procedure for infections may explain the lack of attention of researchers with the topic. (Bays \& Greco, 1992) Despite this, Lanigan and Mintz published a study in 2006 in which they warned of the possible complications of this surgery, including infection. (Laningan \& Mintz, 2002)

Authors such as Spaey et al., (Spaey et al., 2005) who studied infection rates in orthognathic surgery, and Tan and Zwahlen (Tan \& Zwahlen, 2011) who evaluated the effectiveness of prophylactic antibiotic therapy in orthognathic surgery, respectively, excluded patients and articles related to SARME from their studies, further contributing to the difficulty of obtaining data on the subject. Perhaps the lack of interest by scholars about the possibility of infection associated with SARME is the fact that several studies have shown higher rates of this complication in incisions and osteotomies performed in the jaw during orthognathic surgery. This higher infection rate in mandibular procedures has been attributed to the potential for hosting saliva, food debris and other contaminants associated with the difficulty of spontaneous drainage due to gravity, in addition to less blood supply than the maxilla. (Bentley et al., 199; Tan \& Zwahlen, 2011; Baqain et al., 2004; Zijderveld, 1999)

Although the sample is not large, the present study shows numerical homogeneity with no statistically significant difference related to the gender of the patients $(\mathrm{p}=0.640)$. Other studies which evaluated patients undergoing SARME showed 
similar samples. (Babacan et al, 2006; Seeberger et al. 2011)

G1 patients experienced pain at 1,2,7 and 21 days postoperatively with a statistically significant difference compared to G2 patients. In reality, no patient in G2 experienced pain during the postoperative follow-up period, while there were patients with pain complaints in the group which only had the preoperative antibiotic dose in all evaluations. There is no report in the literature to justify such a situation, but the result suggests that there is a possible reduction in bacterial concentration in the surgical wound, thus reducing the signs of the inflammatory process, such as pain. On the other hand, Tzannetou et al. (2008) reported that there is a relative aseptic inflammatory process during SARME and suggested that plaque accumulation should be controlled during treatment to prevent excess biofilm. (Tzannetou et al. 2008)

The local edema observed in the first three assessments of patients in groups I and II suggests that the postoperative use of antibiotics did not influence the characteristics inherent to the inflammatory process of surgical trauma.

We used the 1999 Centers for Disease Control and Prevention (CDC) criteria for the diagnosis of infection, which takes into account the classic clinical signs of the inflammatory process in addition to the presence of abscess and purulent drainage. (Mangram et al. 1999) No patient showed signs of erythema, fever, abscess or drainage of purulent secretion. Therefore, only a few typical signs of inflammation such as pain and edema were seen, and therefore the use of antibiotics prophylactically to avoid the infectious process is not necessary when the surgical procedure occurs following all the necessary biosafety protocols.

Infection rates for clean-contaminated surgeries (Peterson Class II) of around 20-30\% are expected. Still, a good surgical technique combined with antibiotic prophylaxis can reduce the incidence of infections in a Class II surgery to approximately 1\%. (Peterson, 1990) Despite this, our research found lower infection rates. A comparison with a placebo group was not possible due to restrictions from the Hospital Infection Control Center (CCIH) where the surgeries were performed. As part of the protocol established by the $\mathrm{CCIH}$, all patients must be given antibiotic prophylaxis before undergoing surgery under general anesthesia.

In addition to the absence of a placebo group, another limitation of our study was the small sample, which makes it difficult to find differences between the two groups. However, we considered the sum of events displayed by each patient to try to compensate for this limitation in order to increase the sample power.

\section{Conclusion}

Based on the findings of this study, the use of prophylactic antibiotics in SARME is not necessary when the surgical procedure follows all established biosafety protocols. These findings favor a reduction in the costs associated with the procedure and limit adverse reactions with the use of medication, in addition to reducing bacterial resistance. Additional studies with a larger number of patients are necessary to support or refute what was found in this work.

\section{References}

Babacan, H., Sokucu, O., Doruk, C. \& Ay, S. (2006) Rapid maxillary expansion and surgically assisted rapid maxillary expansion effects on nasal volume. Angle Orthod. 76(1), 66-71.

Baqain, Z. H., Hyde, N., Patrikidou, A. \& Harris, M. (2004). Antibiotic prophylaxis for orthognathic surgery: a prospective, randomised clinical trial. $B r J$ Oral Maxillofac Surg. 42(6), 506-10.

Barbosa, I. O., Vieira, B. D., Sales, J. M., dos Santos, M. O., Xavier, W. F., Vilar, E. G. S., Cavalcanti, L. F. De C., Attie, T. M. B.; de Oliveira, T. T. C., Quista, A. A. F., Santos, T. De S. Bone-borne distractor versus tooth-borne distractor for maxillary expansion: a Systematic Review. Research, Society and Development, 9(11), E259119055, 10.33448/rsd-v9i11.9055.

Bays, R. A. \& Greco, J. M. (1992). Surgically assisted rapid palatal expansion: an outpatient technique with long-term stability. J Oral Maxillofac Surg. 50(2), 110-3, discussion 4-5. 
Bentley, K.C., Head, T.W. \& Aiello, G. A. (1999). Antibiotic prophylaxis in orthognathic surgery: a 1-day versus 5-day regimen. J Oral Maxillofac Surg. 57(3), 226-30, discussion 30-2.

Betts, N. J. (2016). Surgically Assisted Maxillary Expansion. Atlas Oral Maxillofac Surg Clin North Am. 24(1), 67-77.

Costelloe, C., Metcalfe, C., Lovering, A., Mant, D. \& Hay, A. D. (2010). Effect of antibiotic prescribing in primary care on antimicrobial resistance in individual patients: systematic review and meta-analysis. Bmj. 340, c2096.

Danda, A. K. \&, Ravi, P. (2011). Effectiveness of postoperative antibiotics in orthognathic surgery: a meta-analysis. J Oral Maxillofac Surg. 69(10), 2650-6.

de Gijt, J. P. Gul, A., Tjoa, S. T., Wolvius, E. B., van der Wal, K.G. \& Koudstaal, M. J. (2017). Follow up of surgically-assisted rapid maxillary expansion after 6.5 years: skeletal and dental effects. Br J Oral Maxillofac Surg. 55(1), 56-60.

Filho, O. G. S., Boas, M. C. \& Capelozza Filho, L. (1991). Rapid maxillary expansion in the primary and mixed dentitions: a cephalometric evaluation. Am J Orthod Dentofacial Orthop. 100(2), 171-9.

Iodice, G., Bocchino, T., Casadei, M., Baldi, D. \& Robiony, M. (2013). Evaluations of sagittal and vertical changes induced by surgically assisted rapid palatal expansion. J Craniofac Surg. 24(4), 1210-4.

Koudstaal, M. J., Poort, L. J., van der Wal, K. G., Wolvius, E. B., Prahl-Andersen, B. \& Schulten, A. J. (2005). Surgically assisted rapid maxillary expansion (SARME): a review of the literature. Int J Oral Maxillofac Surg. 34(7), 709-14.

Koudstaal, M. J., Smeets, J. B., Kleinrensink, G. J., Schulten, A. J. \& van der Wal, K. G. (2009). Relapse and stability of surgically assisted rapid maxillary expansion: an anatomic biomechanical study. J Oral Maxillofac Surg. 67(1), 10-4.

Kraut, R. A. Surgically assisted rapid maxillary expansion by opening the midpalatal suture. (1994). J Oral Maxillofac Surg. 42(10), 651-5.

Lanigan, D. T. \& Mintz, S. M. (2002). Complications of surgically assisted rapid palatal expansion: review of the literature and report of a case. J Oral Maxillofac Surg. 60(1), 104-10.

Mangram, A. J., Horan, T. C., Pearson, M. L., Silver, L. C. \& Jarvis, W. R. (1999). Guideline for Prevention of Surgical Site Infection, 1999. Centers for Disease Control and Prevention (CDC) Hospital Infection Control Practices Advisory Committee. Am J Infect Control. 27(2), 97-132, quiz 3-4, discussion 96.

Northway, W. M. \& Meade, J. B. Jr. (1997). Surgically assisted rapid maxillary expansion: a comparison of technique, response, and stability. Angle Orthod. 67(4), 309-20.

Peterson, L. J. (1990) Antibiotic prophylaxis against wound infections in oral and maxillofacial surgery. J Oral Maxillofac Surg. 48(6), 617-20.

Ruggles, J. E. \& Hann, J. R. (1984) Antibiotic prophylaxis in intraoral orthognathic surgery. J Oral Maxillofac Surg. 42(12), 797-801.

Sato, F. R., Mannarino, F. S., Asprino, L. \& de Moraes, M. (2014) Prevalence and treatment of dentofacial deformities on a multiethnic population: a retrospective study. Oral Maxillofac Surg. 18(2), 173-9.

Schulz, K. F. \& Altman, D. G. \& Moher, D. (2011) CONSORT 2010 statement: updated guidelines for reporting parallel group randomised trials. Int J Surg. $9(8), 672-7$.

Seeberger, R., Kater, W., Schulte-Geers. M., Davids, R., Freier, K. \& Thiele, O. (2011) Changes after surgically-assisted maxillary expansion (SARME) to the dentoalveolar, palatal and nasal structures by using tooth-borne distraction devices. Br J Oral Maxillofac Surg. 49(5), 381-5.

Spaey, Y. J., Bettens, R. M., Mommaerts, M. Y., Adriaens, J., Van Landuyt, H. W., Abeloos, J. V., De Clercq, C. A. S., Lamoral, P. R. B., \& Neyt, L. F. (2005) A prospective study on infectious complications in orthognathic surgery. J Craniomaxillofac Surg. 33(1), 24-9.

Suri, L. \& Taneja, P. (2008) Surgically assisted rapid palatal expansion: a literature review. Am J Orthod Dentofacial Orthop. 133(2), $290-302$.

Tan, S. K., Lo, J. \& Zwahlen, R. A. (2011) Perioperative antibiotic prophylaxis in orthognathic surgery: a systematic review and meta-analysis of clinical trials. Oral Surg Oral Med Oral Pathol Oral Radiol Endod. 112(1), 19-27.

Tan, S. K., Lo, J. \& Zwahlen, R. A. (2011) Are postoperative intravenous antibiotics necessary after bimaxillary orthognathic surgery? A prospective, randomized, double-blind, placebo-controlled clinical trial. Int J Oral Maxillofac Surg. 40(12), 1363-8.

Tzannetou, S., Efstratiadis, S., Nicolay, O., Grbic, J. \& Lamster, I. (2008) Comparison of levels of inflammatory mediators IL-1beta and betaG in gingival crevicular fluid from molars, premolars, and incisors during rapid palatal expansion. Am J Orthod Dentofacial Orthop. 133(5), 699-707.

Zijderveld, S. A., Smeele, L. E., Kostense, P. J. \& Tuinzing, D. B. (1999) Preoperative antibiotic prophylaxis in orthognathic surgery: a randomized, doubleblind, and placebo-controlled clinical study. J Oral Maxillofac Surg. 57(12), 1403-6, discussion 6-7. 